Article

\title{
Production and Characterization of a Bioflocculant Produced by Bacillus salmalaya 139SI-7 and Its Applications in Wastewater Treatment
}

\author{
Zayed M. Abu Tawila ${ }^{1,2}$, Salmah Ismail ${ }^{1, * \mathbb{C}}$, Arezoo Dadrasnia ${ }^{1}$ (1) and \\ Mohammed Maikudi Usman ${ }^{1}$ \\ 1 Institute of Biological Science, Faculty of Science, University of Malaya, Kuala Lumpur 50603, Malaysia; \\ zabutawila@gmail.com (Z.M.A.T.); are.dadrasnia@gmail.com (A.D.); mmusumanu@gmail.com (M.M.U.) \\ 2 Department of Biology, Faculty of Science, Al-Azhar University, Gaza, Palestine \\ * Correspondence: salmah_r@um.edu.my; Tel.: +60-379-672-143
}

Received: 15 August 2018; Accepted: 11 September 2018; Published: 18 October 2018

\begin{abstract}
The production, optimization, and characterization of the bioflocculant QZ-7 synthesized by a novel Bacillus salmalaya strain 139SI isolated from a private farm soil in Selangor, Malaysia, are reported. The flocculating activity of bioflocculant QZ-7 present in the selected strain was found to be $83.3 \%$. The optimal culture for flocculant production was achieved after cultivation at $35.5^{\circ} \mathrm{C}$ for $72 \mathrm{~h}$ at $\mathrm{pH} 7$ \pm 0.2 , with an inoculum size of $5 \%(v / v)$ and sucrose and yeast extract as carbon and nitrogen sources. The maximum flocculating activity was found to be $92.6 \%$. Chemical analysis revealed that the pure bioflocculant consisted of $79.08 \%$ carbohydrates and $15.4 \%$ proteins. The average molecular weight of the bioflocculant was calculated to be $5.13 \times 10^{5} \mathrm{Da}$. Infrared spectrometric analysis showed the presence of carboxyl (COO-), hydroxyl (-OH), and amino $\left(-\mathrm{NH}_{2}\right)$ groups, polysaccharides and proteins. The bioflocculant QZ-7 exhibited a wide $\mathrm{pH}$ stability range from 4 to 7, with a flocculation activity of $85 \%$ at $\mathrm{pH} 7 \pm 0.2$. In addition, QZ-7 was thermally stable and retained more than $80 \%$ of its flocculating activity after being heated at $80{ }^{\circ} \mathrm{C}$ for $30 \mathrm{~min}$. SEM analysis revealed that QZ-7 exhibited a clear crystalline brick-shaped structure. After treating wastewater, the bioflocculant QZ-7 showed significant flocculation performance with a COD removal efficiency of $93 \%$, whereas a BOD removal efficiency of $92.4 \%$ was observed in the B. salmalaya strain 139SI. These values indicate the promising applications of the bioflocculant QZ-7 in wastewater treatment.
\end{abstract}

Keywords: Bacillus salmalaya; bioflocculant; optimization; production; characterization; wastewater treatment

\section{Introduction}

Flocculants are macromolecules with the ability to flocculate suspended solids, cells, and solid colloid particles [1]. Flocculants are widely utilized in separation techniques, such as in drinking water purification, wastewater treatment, activated sludge dehydration, downstream processing, and food fermentation [2]. Flocculants are typically classified into three groups: synthetic organic flocculants such as polyethyleneimine and polyacrylamide byproducts, inorganic flocculants, including aluminum sulfate and polyaluminum chloride, and natural flocculants (bioflocculants) such as chitosan sodium alginate [3].

Bioflocculation is defined as a process in which mediation of flocculants is achieved in the presence of microorganisms or biodegradable macromolecular flocculants released by microorganisms [4]. A number of microorganisms (i.e., bacteria, algae, fungi, and actinomycetes) are considered producers of bioflocculants [5]. Bioflocculants such as diatom silica shells and Arthrobacter spp. biomass are applicable in removing heavy metals, including arsenate, from wastewater [6,7]. 
Bioflocculation is considered an active process caused by living cells due to the production of exopolymeric macromolecules. The flocculation process in microorganisms was first reported in yeast by Louis Pasteur in 1876 [2]. Microbial biopolymers have gained attention as anti-bacterial, anti-viral and anti-algal agents. In addition, they are considered inducers of microbial aggregation and biofilm formation. Moreover, microbial flocculants are also applied in different industries such as the food and pharmaceutical industries as viscosifying, emulsifying, and stabilizing agents, for the purification of potable water, and wastewater treatment [8]. Bioflocculants have been used as biosorbents for removing all types of metallic pollutants from manufacturing wastes [9]. Flocculation and coagulation processes are cost-effective methods used as primary treatment for drinking water [10]. Many inexpensive chemical compounds with high flocculation properties, such as ferric chloride, polyacrylamide, and polyaluminum chloride, are extensively used in such treatments [11]. Zhang et al. [3] reported that some flocculants pose a risk to human health; for example, aluminum salts are associated with Alzheimer's disease. Moreover, monomeric units of acrylamide can lead to severe neurotoxic and carcinogenic effects. Zhang et al. [3] indicated that acrylamides are nondegradable in nature, and the use of these flocculants is now limited or banned in several countries. Due to their biodegradability and nontoxicity for the environment and human health, bioflocculants could be an alternative to inorganic and synthetic organic flocculants [4,12]. However, despite the fact that bioflocculants of natural origin are biodegradable and safe in application, they often exhibit inadequate flocculating activity [13]. Therefore, the search for new bioflocculants that are both biodegradable and display powerful flocculation capability is attracting much research attention. Various bioflocculants can be derived from different bacteria; the produced bioflocculants can be optimized and characterized. For instance, Bacillus licheniformis [14], Nocardia amarae YK1 [15], Pacilomyces sp. [13], and Rhodococcus erythropolis S-I [16] all produce flocculating proteins. Species that produce polysaccharide bioflocculants include Bacillus subtilis IFO3335 [17] and Alcaligenes latus KT201 [18], while Arathrobacter sp. [19] and Arcuadendron sp. TS-4 [20] produce glycoprotein bioflocculants.

Members from the genus Bacillus belonging to the phylum Firmicutes are classified as Gram-positive and spore-forming bacteria with a rod-shaped structure. Bacillus species can tolerate facultative anaerobes or obligate aerobes. They comprise naturally ubiquitous pathogenic and free-living species [21]. Moreover, various industrially important species from this genus have a reported history of safe applications in both the pharmaceutical and food industries [5]. For instance, Bacillus amyloliquefaciens, Bacillus clausii, B. licheniformis, Bacillus megaterium, and B. subtilis were reported to have several advantages in industrial applications [22]. In agricultural biotechnology, many Bacillus-derived products serve as microbial biofertilizers, fungicides, or pesticides [23]. Bacillus amyloliquefaciens is identified for the synthesis of a ribonuclease (an antibiotic protein occurring in nature), $\alpha$-amylase, and proteases protein synthesis [24]. The main factors preventing their wider production and industrial application include low yields, high cost of production, and low flocculating activity $[25,26]$. Therefore, screening and identifying new microorganisms that produce bioflocculants, as well as h programs for the optimization of fermentation conditions, that can help enhance bioflocculant yield are important objectives [27,28]. Industrial wastewater treatment is a hot research topic worldwide, and flocculation is considered a remarkable method for removing pollutants from wastewater [29].

The present study aimed to investigate the potential of Bacillus salmalaya strain 139SI to produce bioflocculants, as well as to optimize and characterize the produced bioflocculant QZ-7. The study also determined the ability of the B. salmalaya strain 139SI to remove organic matter measured as biological oxygen demand (BOD) and the newly produced bioflocculant QZ-7 to remove organic matter measured as chemical oxygen demand (COD) from wastewater. 


\section{Results and Discussion}

\subsection{Selection of the Bacterial Strain for Bioflocculant Production}

Bacterial strains were screened for bioflocculant production. From 15 colonies, five strains presented the highest flocculating activity as shown in Table 1. The maximum flocculating activity was $83.3 \%$ for B. salmalaya strain 139 SI-7. This selected strain was tested for the optimization of bioflocculant production.

Table 1. Flocculating activity values for the selected strains.

\begin{tabular}{ccc}
\hline Strain Code No & Flocculating Activity (\%) & Standard Deviation (SD) \\
\hline BS * 139SI-1 & 67.5 & 0.655 \\
BS 139SI-5 & 54.2 & 0.770 \\
BS 139SI-7 & 83.3 & 0.75 \\
BS 139SI-8 & 72.2 & 1.93 \\
BS 139SI-13 & 63.4 & 0.45 \\
\hline
\end{tabular}

${ }^{*} \mathrm{BS}$ is Bacillus salmalaya.

\subsection{Optimization of B. salmalaya Strain 139SI-7 for Bioflocculant Production}

\subsubsection{Effect of $\mathrm{pH}$}

The initial $\mathrm{pH}$ of the fermentation medium directly influenced the synthesis of the bioflocculant QZ-7. Flocculating activity in the fermentation broth culture start gradually increased from $38.6 \%$ at $\mathrm{pH} 3$ to $83.7 \%$ at $\mathrm{pH} 7$ and gradually decreased to $28.8 \%$ at $\mathrm{pH} 11$ as shown in Figure 1 . The optimal $\mathrm{pH}$ for bioflocculant production was obtained at neutral $\mathrm{pH}(\mathrm{pH} 7 \pm 0.2)$. All subsequent experiments were conducted at $\mathrm{pH} 7 \pm 0.2$. A similar result was obtained for bioflocculant TKF04 production produced by Citrobacter spp. [30] and the increase in bioflocculant yield differs in different strains at their optimal $\mathrm{pH}$ [31]. The nutrient absorption capability of the cells and the presence of high electric charge could influence enzymatic reactions [32,33] thereby decreasing flocculating activity. At neutral $\mathrm{pH}$, the nutrient absorption capability of the cells was high due to the neutral electric charge, indicating that the highest flocculation activity was observed in the broth culture.

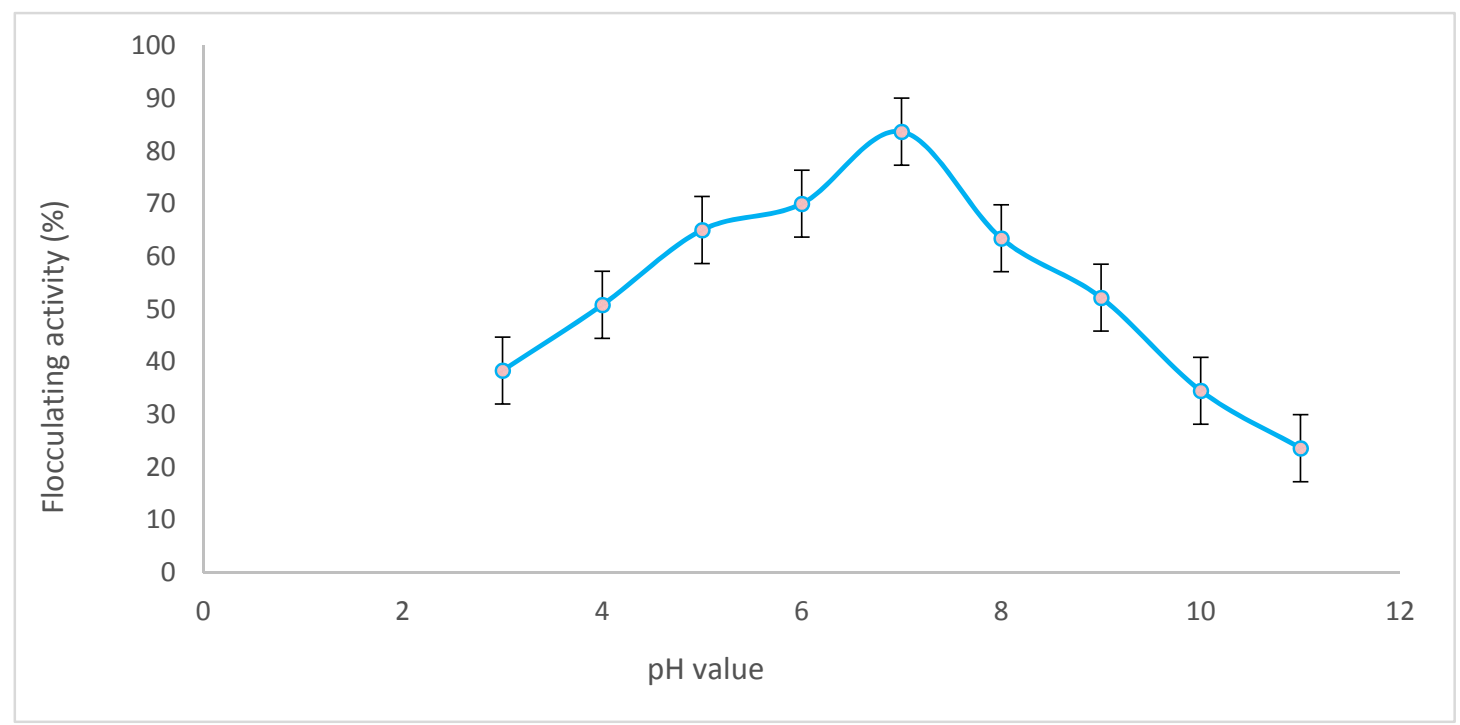

Figure 1. Effect of $\mathrm{pH}$ on bioflocculant production. 


\subsubsection{Effect of Inoculum Size}

The influence of inoculum volume on bioflocculant production was determined according to [34] using a range of bacterial inoculum sizes from $0.1 \%$ to $10 \%(v / v)$. The different inoculum volumes showed a certain effect on the flocculating activity and cell mass values, as shown in Figure 2. Flocculating activity increased from $53.2 \%$ at an inoculum size of $0.1 \%(v / v)$ to $83.6 \%$ at an inoculum size of $5 \%(v / v)$, followed by a decrease to $72.4 \%$ at an inoculum size of $10 \%(v / v)$. The obtained optimal inoculum size was $5 \%(v / v)$, which was used in all following experiments. The outcome results were analogous to those reported by Wang et al. [34] where an optimal inoculum volume of $5 \%$ was detected for Klebsiella mobilis. The maximum flocculation activity was not in agreement with the maximum cell growth, but the flocculation activity for B. salmalaya strain 139SI was maintained within a certain range of inoculum volume. This condition was due to the influence of inoculum volume on microbial growth. A small inoculum volume extended the lag phase growth, while outsized inoculum made the niche of the strain overlap extremely, subsequently inhibiting the production due to inadequate supply of nutrients [35].

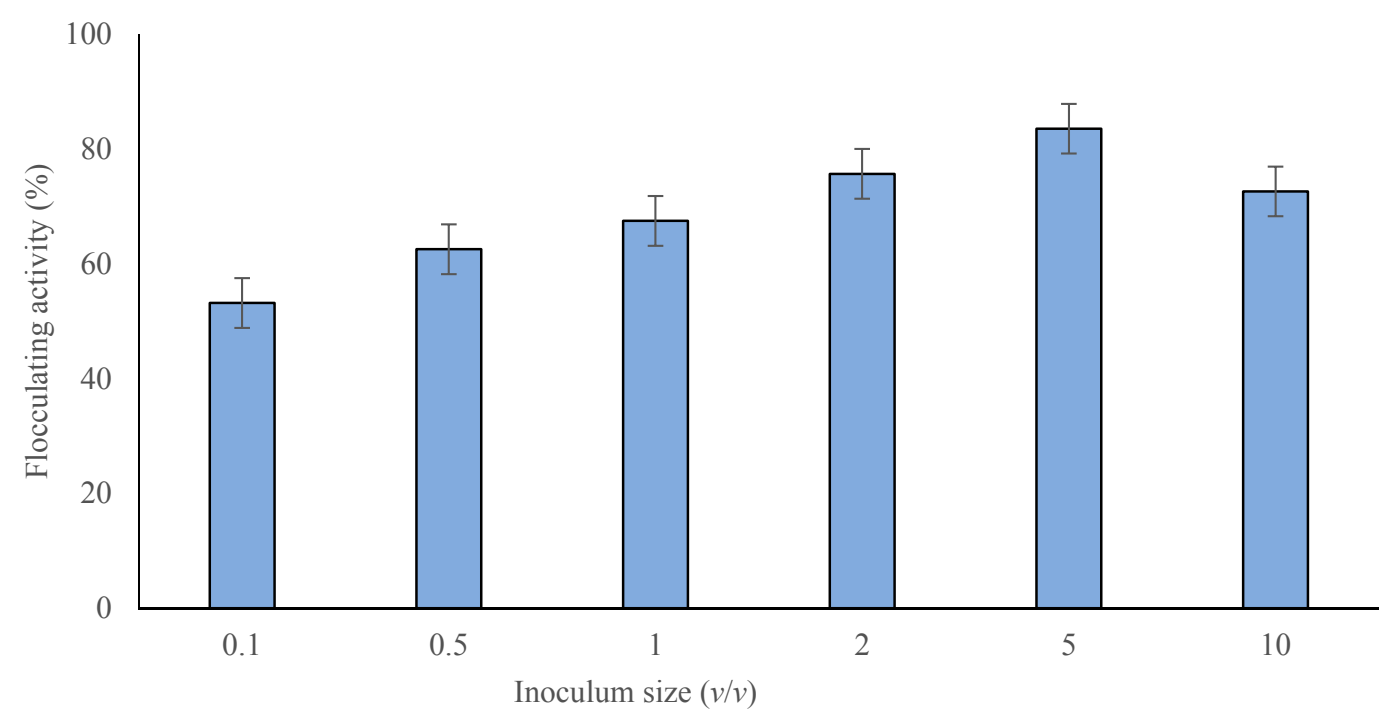

Figure 2. Effect of inoculum size on bioflocculant production.

\subsubsection{Effect of Temperature}

The influence of temperature and shaking speed were used to investigate the bioflocculating activity of the bioflocculant. Figure 3 shows that the flocculating activity of bioflocculant was about $81.9 \%$, when the culture temperature was at $35^{\circ} \mathrm{C}$, which was a best flocculating activity in the experiments. When the temperature was over $40^{\circ} \mathrm{C}$, the flocculating activity of the bioflocculant gradually declined. The optimal temperature for bioflocculant production was $37^{\circ} \mathrm{C}$, which was used for the following studies. The metabolism of microorganisms is directly related to culture temperature [2,32]. Maximum enzymatic activation can only be obtained at an optimum temperature [36]. 


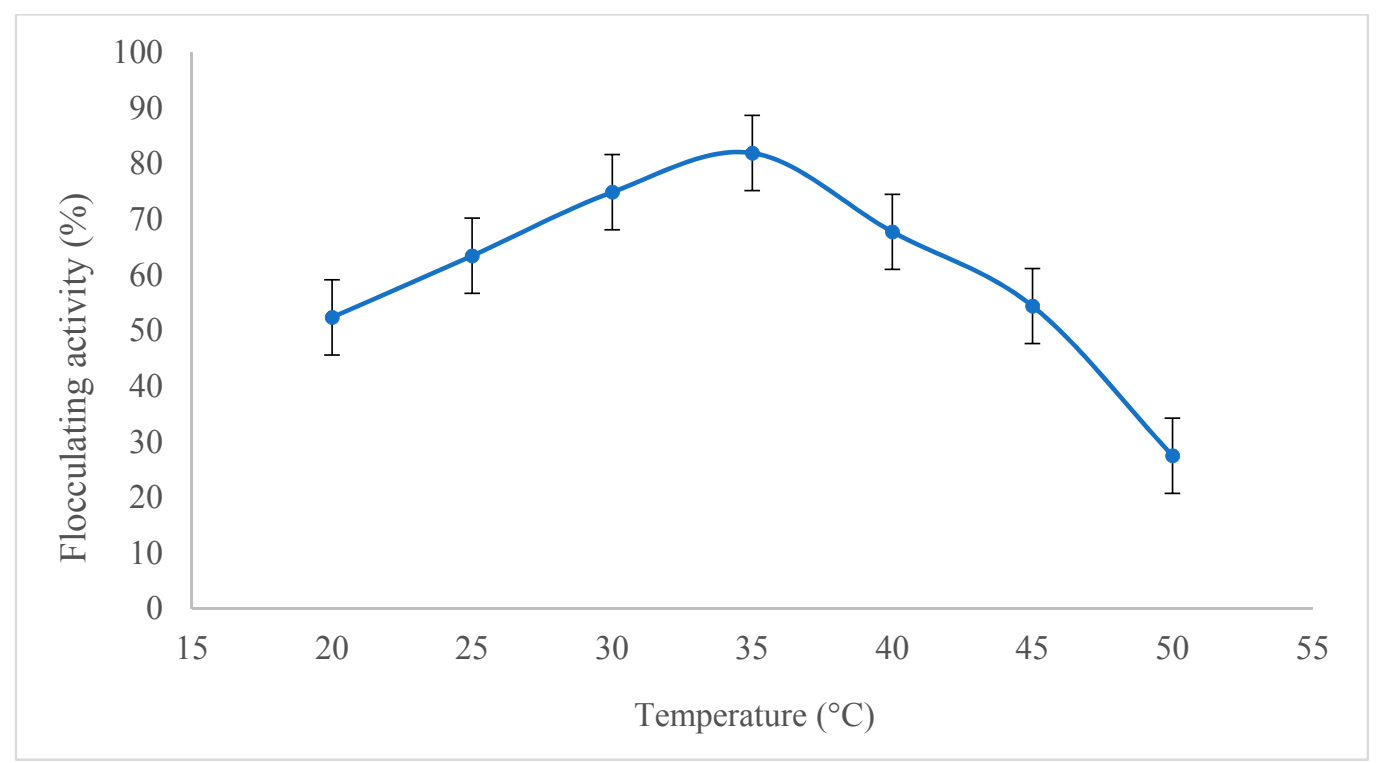

Figure 3. Effect of cultivation temperature on bioflocculant production.

\subsubsection{Effect of Shaking Speed}

The effect of shaking speed on bioflocculant production is shown in Figure 4. The optimum shaking speed was found to be $160 \mathrm{rpm}$, with highest flocculating activity reached $83.6 \%$. Also, flocculating activity start gradually in an increase from 100 to $160 \mathrm{rpm}$. While higher shaking speed than the optimum caused a decline in the flocculating activity. The shaking speed of $160 \mathrm{rpm}$ was used in the following experimental studies. The shaking speed determines the dissolved oxygen concentration, which can also affect nutrient absorption and enzymatic reaction [36]. In the course of the early growth phase, the biomass and bioflocculant production were lower, resulting in lower viscosity of culture broth and oxygen demand, when the strain B. salmalaya 139SI proceed in the logarithmic and stationary phases, the biomass and the bioflocculant production increased, and the corresponding viscosity of the culture broth and the oxygen demand also increased.

\subsubsection{Effect of Carbon Source}

Bioflocculant synthesis is greatly affected by the type of carbon source used. The effect of carbon sources including sucrose glucose, lactose, maltose, fructose, and starch as single sources on bioflocculant synthesis by B. salmalaya strain 139SI was evaluated as shown in Figure 5. In addition, the bioflocculant synthesis was also tested under the effect of a mixture of carbohydrate $(\mathrm{CHO})$ which includes sucrose and glucose. The highest $90.1 \%$ and the lowest $29 \%$ of flocculating activities were obtained with mixed carbohydrate source and starch, respectively. Moreover, as single carbon sources such as sucrose, glucose, lactose, and maltose were markedly appropriate for bioflocculant production with a flocculating activity exceeding $60 \%$ after $72 \mathrm{~h}$ of cultivation period. Aljuboori et al. [37] found that sucrose is the most desirable carbon source to Aspergillus flavus for bioflocculant production. 


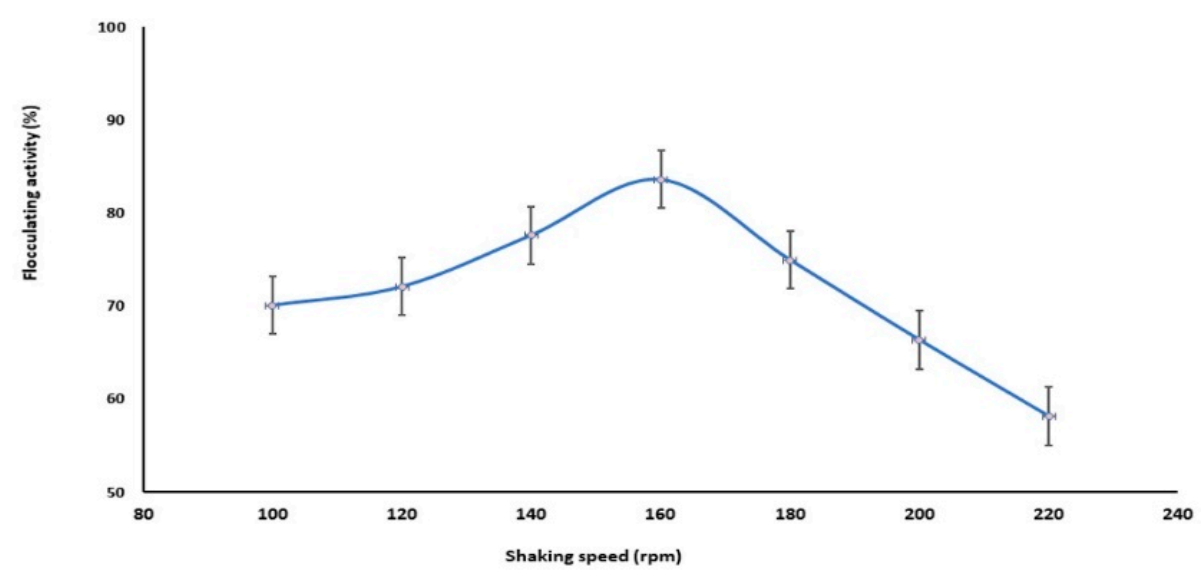

Figure 4. Effect of shaking speed on bioflocculant production.

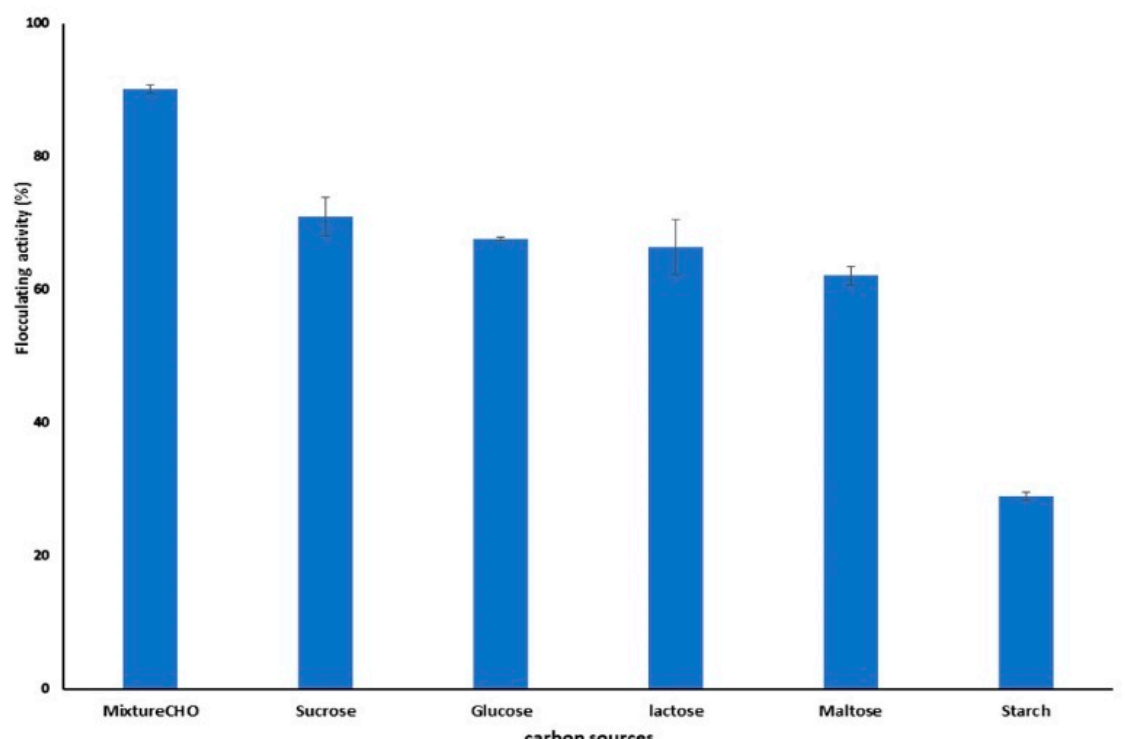

Figure 5. Effect of carbon source on bioflocculant production.

\subsubsection{Effect of Nitrogen Source}

The nitrogen source plays a crucial role in the synthesis of bioflocculants [38]. The effect of nitrogen source on production was evaluated using different sources of organic origin, such as yeast extract, tryptone, peptone, urea, and ammonium sulfate was used as a source of inorganic nitrogen. In addition, the bioflocculant synthesis was also tested under the effect of a mixture of nitrogen which included urea and yeast extract. Different microorganisms utilize nitrogen derived from both or either inorganic or organic sources for production [39]. The influence of nitrogen sources, both organic and inorganic, on bioflocculant synthesis by B. salmalaya strain 139SI is illustrated in Figure 6. The highest flocculation activity reached at $72 \mathrm{~h}$ of cultivation was obtained with mixed nitrogen source $72.1 \%$, while yeast extract gives $64.5 \%$ and urea $61.5 \%$, whereas the lowest activity was detected with peptone $42.5 \%$. While the ammonium sulfate as inorganic nitrogen gives about $58.86 \%$ of flocculating activity. As reported by Ugbenyen et al. [40], flocculating activity was peaked with yeast extract followed by casein hydrolysate and tryptone. A similar finding indicated that organic nitrogen is more appropriate for bioflocculant production than inorganic nitrogen because it is easily absorbed by microbial cells in relation to the nitrogen source of inorganic origin [38]. Moreover, Ismail and Nampoothiri [41] indicated that yeast extract was a highly favorable nitrogen source that improved EPS production by Lactobacillus planetarium MTCC 9510. 


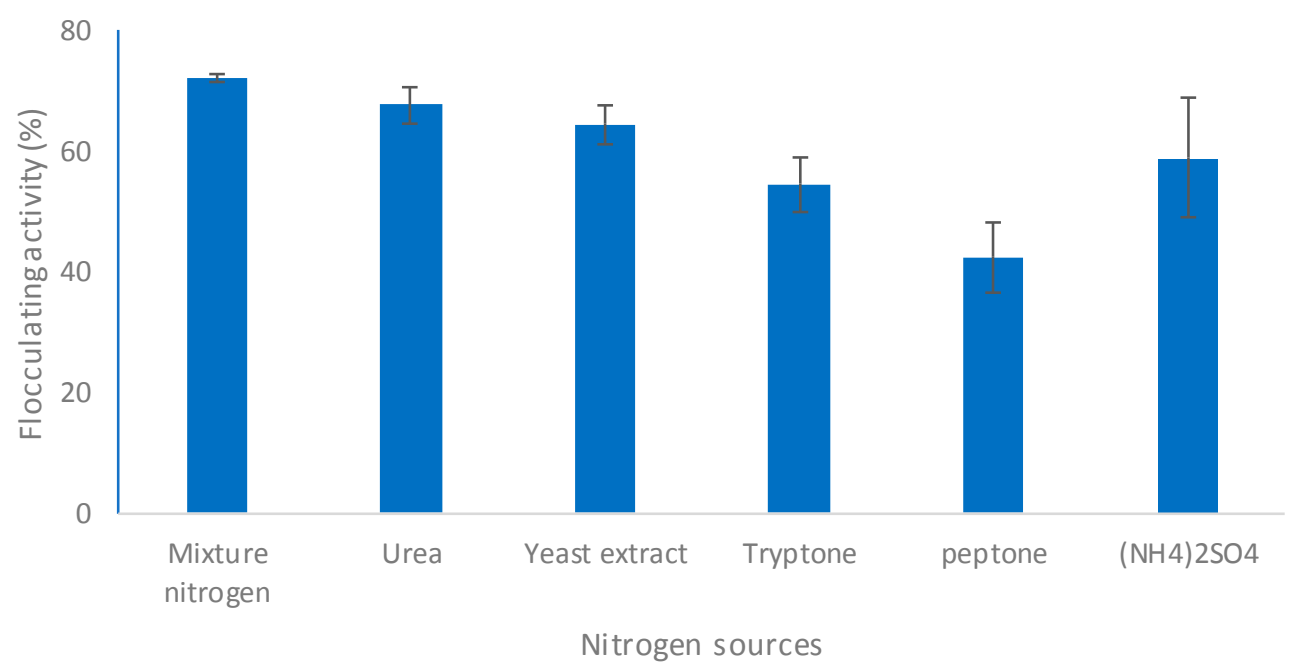

Figure 6. Effect of nitrogen source on bioflocculant production.

\subsection{Bioflocculant Production by B. salmalaya Strain 139SI-7}

Optimal culture conditions were set for bioflocculant production by B. salmalaya 139SI. Figure 7 shows the time course assay of bioflocculant production. The produced amount of bioflocculant was $2.7 \mathrm{~g} / \mathrm{L}$.

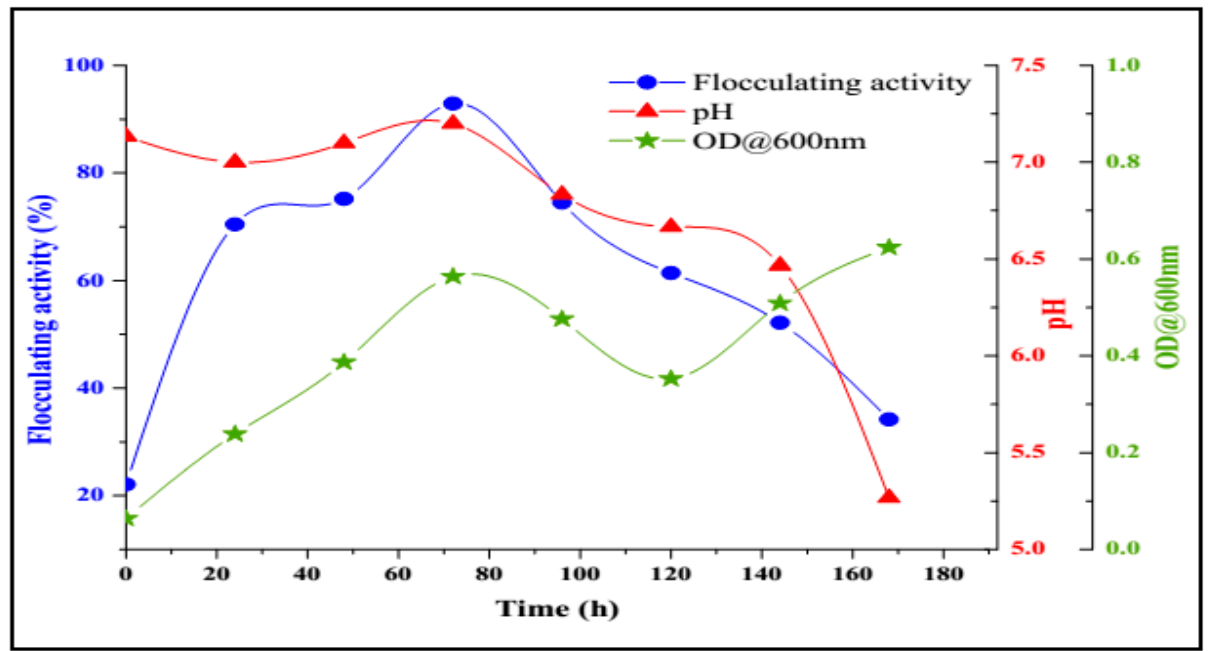

Figure 7. Time course of bioflocculant production by Bacillus salmalaya 139SI.

As expected, no cell growth was observed within the first $12 \mathrm{~h}$ of cultivation (lag phase). However, after this period a steady increase in cell growth convoyed by a parallel increase in flocculating activity was detected. The stationary growth phase was attained after $72 \mathrm{~h}$ of cultivation. Flocculating activity ran parallel to cell growth, thereby exhibiting a concomitant increase in bioflocculant production with cell growth. Flocculating activity reached its maximum flocculation peaked at $92.6 \%$ at the late stationary phase $(72 \mathrm{~h})$, and a further expansion in cultivation period lead in a decrease in both flocculating activity and cell growth. This observation indicated that the production of bioflocculant was a result of biosynthesis during bacterial growth and not via cell autolysis [4]. The decrease in flocculating activity detected after $72 \mathrm{~h}$ might be attributed to the existence of bioflocculant-degrading enzymes produced by the microorganisms [42]. A similar study was reported by Zheng et al. 2008 [39], who found that the flocculating activity of the bioflocculant produced by Serratia fiacre and Bacillus sp. F19 reaches its maximum at the early stationary phase 
of $72 \mathrm{~h}$. The initial $\mathrm{pH}$ of the production medium was adjusted to 7 and then monitored at regular intervals over the entire fermentation period. Moreover, the $\mathrm{pH}$ of the production medium governs the oxidation-reduction potential and the cells electrical charge thereby affecting enzymatic reaction and nutrient absorption [2]. Consequently, the $\mathrm{pH}$ of the fermentation medium decreased as cultivation period increased time. The decrease in $\mathrm{pH}$ of the fermentation medium might be due to the production of organic acids as a result of glucose metabolism, because glucose was a constituent of the production medium or the presence of organic acids metabolically produced by bacteria [43].

\subsection{Characteristics of Bioflocculant QZ-7}

The composition of bacterial bioflocculants plays a role in their flocculating activities [44] reports showed that numerous types of bioflocculants comprise proteins, polysaccharides, glycoproteins, and glycolipids [9]. On the basis of the chemical analysis of the produced bioflocculant, the total carbohydrate and protein compositions were $79.08 \%$ and $15.4 \%$, respectively. These results are inconsistent with Chaplin and Kennedy [45]. The bioflocculant was mainly composed of polysaccharides and proteins. Further analysis revealed the presence of uranic acid in the bioflocculant. With an adequate proportion of uranic acid molecules in the bioflocculant, carboxyl groups can be added to the molecular chain. The carboxyl group present in the molecular sequence affords more active sites for constituent parts, so several elements can bind to the elongated molecular chain [46].

\subsection{FTIR}

Infrared spectrophotometry was used to analyze the purity of the bioflocculant as illustrated in Figure 8. Clear absorption peaks were observed at 3420.56, 2929.82, 2437.35, 2176.08, 2073.19, $1658.90,1432.97,1187.49,1109.66,924.94,618.50,535.79$, and $476.32 \mathrm{~cm}^{-1}$. The absorbed stretching $\mathrm{O}-\mathrm{H}$ band was at $3420.56 \mathrm{~cm}^{-1}$, and a vibration weak band of C-H was noted at 2929.82 and $2073.19 \mathrm{~cm}^{-1}$. This result was similar to the results obtained by Deng 2005 [11]. The peaks at 1658.90 and $1432.97 \mathrm{~cm}^{-1}$ were attributed to $\mathrm{C}=\mathrm{O}$ stretching and $\mathrm{COOH}$ vibration, respectively, whereas that at $1432.97 \mathrm{~cm}^{-1}$ was due to the $\mathrm{C}=\mathrm{O}$ antisymmetric extension in the carboxylate [47], thereby showing the existence of carboxylate function groups in QZ-7. The carboxyl group may also serve as a functional moiety for the generation of modified or new polymers in different forms via different approaches, such as a unique designed formulation by assembling such polymers to other synthetic polymers. Other bands observed at 1109.66 and $1187.49 \mathrm{~cm}^{-1}$ were identified to be classic characteristics of all compounds derived from sugar, including sugar derivatives such as manuronic acid, guluronic acid, and uranic acid [48]. Other absorption bands at 924.94 and $990.44 \mathrm{~cm}^{-1}$ were related to the $\beta$-glycosidic bond linking the monomeric units present in sugars [49]. The corresponding small band absorptions were observed at $446.32,538.79$, and $618.50 \mathrm{~cm}^{-1}$, which indicated that the bioflocculant QZ-7 was a protein-bound polysaccharide [25]. 


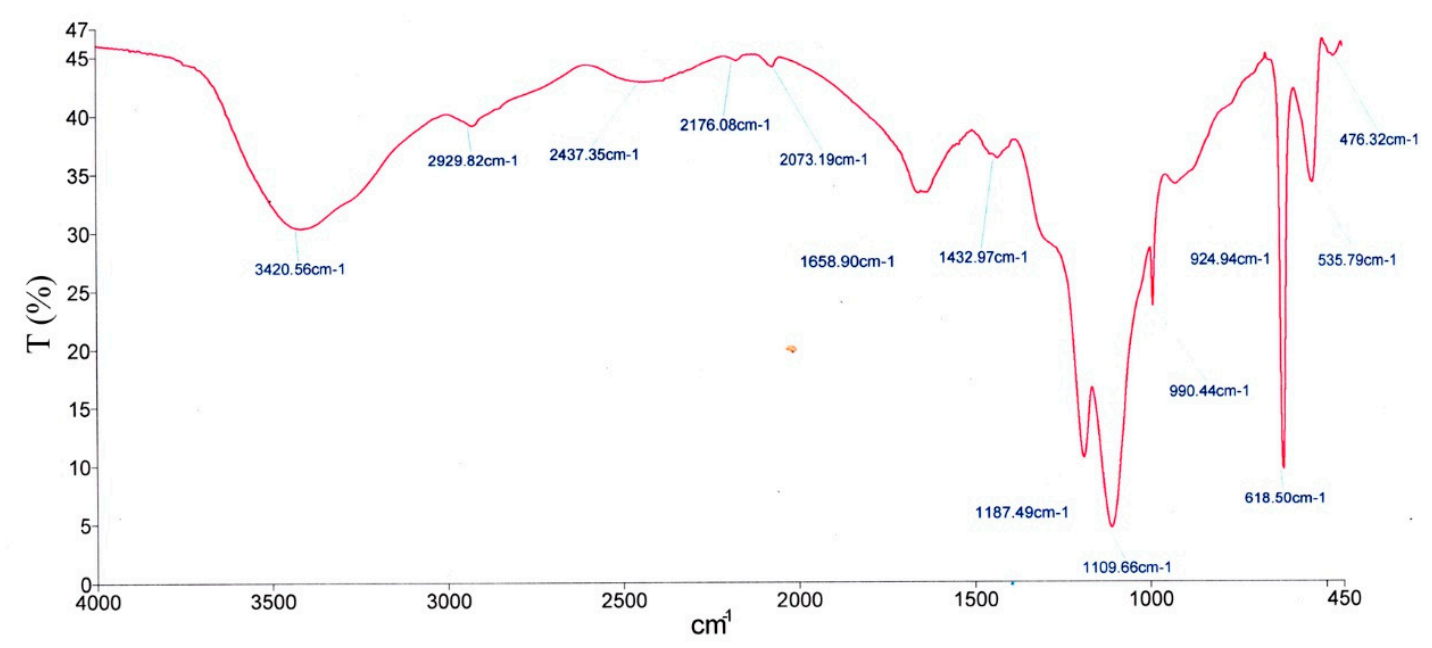

Figure 8. Fourier-transform infrared spectroscopy.

\subsection{Molecular Weight Analysis}

The HPGPC spectrum of the purified bioflocculant exhibited a symmetrical and sharp peak in the retention time of 6.53 and 9.95. The molecular mass-retention time equation in accordance with the calibration curve was expressed as follows:

$$
\log (\text { molecular weight })=-0.1368 \mathrm{~T}+8.3496
$$

The average weight of the bioflocculant was calculated to be $5.13 \times 10^{5} \mathrm{Da}$, which was much higher than the weight of other bioflocculants [50]. Bioflocculants with high molecular weight present stronger bridging, more adsorption points, and higher flocculating activities than those with low molecular weight [7].

\subsection{SEM Imaging}

The morphological surface structure of QZ-7 was illuminated prior to and after the flocculation process with kaolin clay particles. As shown in Figure 9A, QZ-7 was gray with a condensed crystalline brick-shaped structure. This structure served as an attachment site to which suspended particles and cations could bind [2]. Figure 9B illustrates how the bioflocculant aggregated the kaolin particles, which resulted in the formation of large flocs that were easily sedimented. Therefore, SEM images of QZ-7 and flocculating kaolin particles indicated that bridging could be liable for the flocculation capability of QZ-7. In accordance with our observation, previous studies also reported related incidences with some bioflocculants [24,51]. 

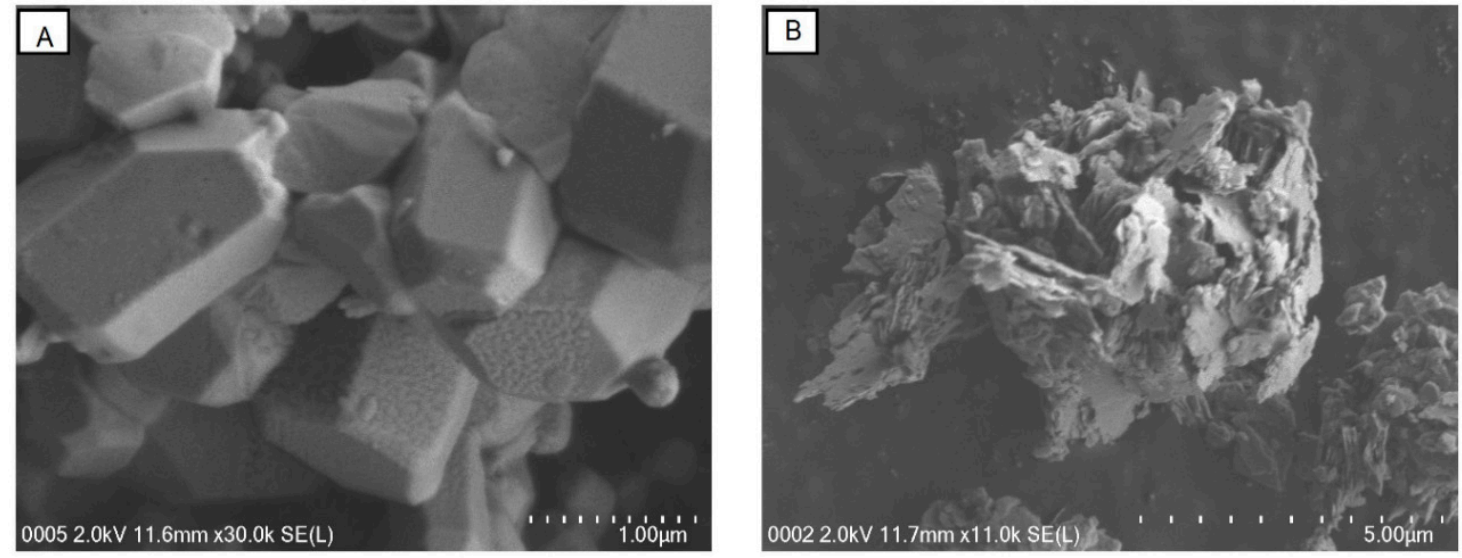

Figure 9. SEM micrograph, (A) purified bioflocculant QZ-7; (B) bioflocculant aggregation with kaolin clay.

\section{8. $\mathrm{pH}$ and Thermo-Stability of Pure Bioflocculant QZ-7}

As shown in Figure 10, QZ-7 was found to be fairly steady at a wide $\mathrm{pH}$ range of 4-7, and about $85 \%$ flocculating activity was observed at this range. Therefore, QZ-7 was considered useful in neutral and acidic conditions, whereas a $\mathrm{pH}$ greater than 7 decreased the degree of flocculation activity. QZ-7 displays diverse electric statuses at varying $\mathrm{pH}$ ranges, and this characteristic may affect the flocculating capability of QZ-7 for kaolin units [52]. The influence of temperature on the flocculation activity of the purified QZ-7 was investigated. As shown in Figure 10, over 70\% of flocculating activity was sustained at $20{ }^{\circ} \mathrm{C}-80{ }^{\circ} \mathrm{C}$ and $\mathrm{pH} 4-7$. The thermal strength of this bioflocculant was attributed to the core backbone of QZ-7, which comprises polysaccharides [43]. The bioflocculant with polysaccharide-based structure are generally thermal-stable, but those with protein are sensitive to temperature $[10,53]$. High temperatures may result in the degradation of polysaccharide chains and diminish flocculating activity. The thermal activity of the biopolymer was investigated by other studies using different bioflocculants [2].

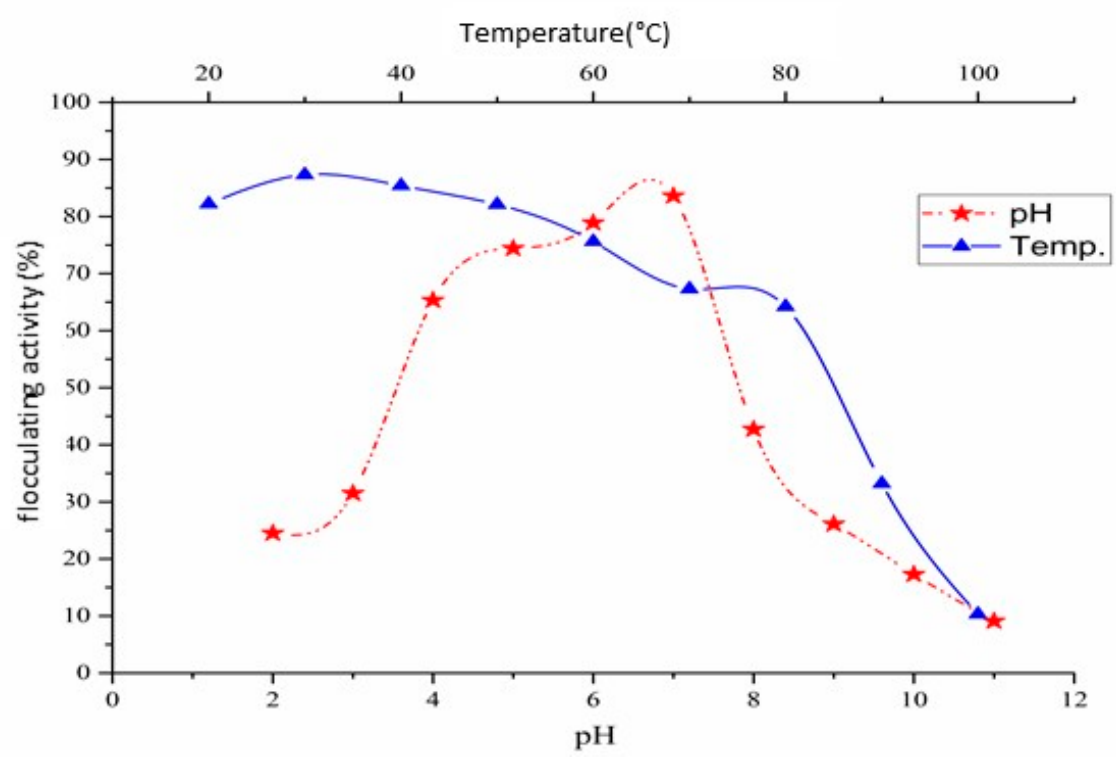

Figure 10. Thermal and $\mathrm{pH}$ stability of the purified QZ-7.

\subsection{Wastewater Treatment with Bioflocculants}

The crude bioflocculant produced by B. salmalaya 139SI was used to treat industrial wastewater with an initial COD concentration of $15,268 \mathrm{mg} / \mathrm{L}$. After the treatment, the final COD concentration 
dropped to $1065 \mathrm{mg} / \mathrm{L}$, and the COD removal rate was 93\%. Therefore, the bioflocculant QZ-7 could be used for the removal of COD from wastewater. The B. salmalaya strain 139SI-7 was used to treat an industrial wastewater with an initial BOD concentration of $4018 \mathrm{mg} / \mathrm{L}$. After treatment, the final BOD concentration was $302 \mathrm{mg} / \mathrm{L}$. The percentage of BOD removal estimated by Equation (2) was 92.4\%. Hence, B. salmalaya strain 139SI could be used for the removal of BOD from wastewater.

\section{Conclusions}

In this research, a production, optimization, and characterization of bioflocculant QZ-7 synthesized by a novel Bacillus salmalaya strain 139SI isolated from a private farm soil in Selangor, Malaysia, were conducted. Results show that the flocculating activity of bioflocculant QZ-7 present in the selected strain was found to be $83.3 \%$. The optimal culture for flocculants production was achieved at $\mathrm{pH} 7 \pm 0.2$, with an inoculum size of $5 \%(v / v)$ and sucrose and yeast extract as carbon nitrogen sources after cultivation at $35{ }^{\circ} \mathrm{C}$ for $72 \mathrm{~h}$. After optimization, the bioflocculant was increased by $10 \%$. The maximum flocculating activity was found to be $92.6 \%$. Chemical analysis revealed that the pure bioflocculant consisted of $79.08 \%$ carbohydrates and $15.4 \%$ proteins. The average molecular weight of the bioflocculant was calculated to be $5.13 \times 10^{5} \mathrm{Da}$. Infrared spectrometric analysis showed the presence of carboxyl (COO-), hydroxyl (-OH), and amino (-NH3) groups; polysaccharides; and proteins. The bioflocculant QZ-7 exhibited wide $\mathrm{pH}$ stability ranging from 4 to 7 , with a flocculation activity of $85 \%$ at $\mathrm{pH} 7 \pm 0.2$. In addition, QZ-7 was thermally stable and retained more than $80 \%$ of its flocculating activity after being heated at $80{ }^{\circ} \mathrm{C}$ for $30 \mathrm{~min}$. After treating the wastewater, the bioflocculant QZ-7 showed significant flocculation performance with a COD removal efficiency of $93 \%$, whereas a BOD removal efficiency of $92.4 \%$ was observed in the B. salmalaya strain 139 SI. These values indicate the promising application of the bioflocculant QZ-7 in wastewater treatment.

\section{Materials and Methods}

\subsection{Cultivation and Isolation of the Bacteria}

The B. salmalaya strain 139SI was obtained from the Molecular Bacteriology and Toxicology laboratory at the University of Malaya. The bacterial isolate was originally obtained from soil samples obtained from a private farm located at $2.99917^{\circ} \mathrm{N}$ and $101.70778^{\circ} \mathrm{E}$ in Selangor, Malaysia. The bacterium was identified as B. salmalaya strain 139SI and deposited in Gen Bank KM0511837 [54]. The selected strain was streaked on blood agar medium plates and incubated at $37{ }^{\circ} \mathrm{C}$ for $18-24 \mathrm{~h}$. The bacterial colonies exhibiting $\beta$-hemolytic activities were obtained and subcultured on slant tubes of nutrient agar. The subcultures were incubated under aerobic conditions at $37^{\circ} \mathrm{C}$ for $24 \mathrm{~h}$. This bacterial strain was consistently cultivated on nutrient agar and preserved in glycerol solution $(20 \%, w / v)$ suspended at $-80^{\circ} \mathrm{C}$.

\subsection{Composition of the Used Media}

Two types of media, namely, seed media and production media, were used to screen and obtain the produced bioflocculant. The seed medium had the following components (in $\mathrm{g} / \mathrm{L}$ ): $10 \mathrm{~g}$ of glucose, $1.5 \mathrm{~g}$ of yeast extract, $1.5 \mathrm{~g}$ of urea, $0.1 \mathrm{~g}$ of $\mathrm{KH}_{2} \mathrm{PO}_{4}, 0.1 \mathrm{~g}$ of $\mathrm{NaCl}$, and $0.2 \mathrm{~g}$ of $\mathrm{MgSO}_{4} \cdot 7 \mathrm{H}_{2} \mathrm{O}$. The $\mathrm{pH}$ was adjusted to $7.0 \pm 0.2$. The production medium contained the following components (in $\mathrm{g} / \mathrm{L}$ ): $10 \mathrm{~g}$ of sucrose, $5 \mathrm{~g}$ of glucose, $1.5 \mathrm{~g}$ of yeast extract, $1.5 \mathrm{~g}$ of urea, $0.1 \mathrm{~g}$ of $\mathrm{KH}_{2} \mathrm{PO}_{4}, 0.1 \mathrm{~g}$ of $\mathrm{K}_{2} \mathrm{HPO}_{4}, 0.1 \mathrm{~g}$ of $\mathrm{NaCl}$, and $0.2 \mathrm{~g}$ of $\mathrm{MgSO}_{4} \cdot 7 \mathrm{H}_{2} \mathrm{O}$. The $\mathrm{pH}$ was adjusted to $7.0 \pm 0.2$ [55].

\subsection{Screening for Bioflocculant-Producing Bacteria}

Fifteen colonies of B. salmalaya strain 139SI were pre-cultured in 15 McCartney bottles each containing $10 \mathrm{~mL}$ of the production medium. The bottles were incubated at $35.5^{\circ} \mathrm{C}$ and shaken at $150 \mathrm{rpm}$ for $24 \mathrm{~h}$. Subsequently, 2\% of each culture broth was seeded into $100 \mathrm{~mL}$ of fermentation 
medium. The seeded flasks were also incubated at $35.5^{\circ} \mathrm{C}$ for $24 \mathrm{~h}$ at $150 \mathrm{rpm}$. For cell separation, the fermented culture was harvested via centrifugation at $4000 \mathrm{rpm}$ for $30 \mathrm{~min}$ [50].

\subsection{Determination of Flocculating Activity}

To select the best strain that produced bioflocculants, flocculating activity was determined from the cell-free supernatants. The flocculating activity was analyzed using a suspension of kaolin clay. The suspension was prepared by mixing $4.0 \mathrm{~g}$ of kaolin clay in $1.0 \mathrm{~L}$ of distilled water [56]. A mixture of $95 \mathrm{~mL}$ of kaolin suspension with $3 \mathrm{~mL}$ of $1.0 \%$ calcium chloride $\left(\mathrm{CaCl}_{2}\right)$ solution and $2.0 \%(\mathrm{v} / \mathrm{v})$ cell-free supernatant was prepared. The mixed solution was vigorously agitated and left to settle at room temperature for $5 \mathrm{~min}$. The optical density (OD550) of the obtained clarified solutions was determined via spectrophotometry at $550 \mathrm{~nm}$ (UV-1700 spectrophotometer, Shimadzu, Kyoto, Japan). A control sample was prepared in the same way, except the cell-free supernatant was replaced with unfermented broth media. The flocculating activity was calculated using the following expression [56]:

$$
\text { Flocculating activity } \%=\left(\mathrm{A}_{\mathrm{c}}-\mathrm{B}_{\mathrm{s}}\right) / \mathrm{A}_{\mathrm{c}} \times 100
$$

where $A_{c}$ and $B_{S}$ represent the OD of the control and real samples, respectively.

\subsection{Optimization of Cultural Conditions for Bioflocculant Production}

\subsubsection{Effect of $\mathrm{pH}$}

The effect of $\mathrm{pH}$ on the production medium was determined at different $\mathrm{pH}$ values ranging from 3-11 adjusted by adding $1 \mathrm{~N} \mathrm{HCl}$ and $1 \mathrm{~N} \mathrm{NaOH}$ as needed. A fresh culture of $2 \%(v / v)$ B. salmalaya strain 139SI-7 was inoculated into the prepared medium, incubated for $72 \mathrm{~h}$ at $35^{\circ} \mathrm{C}$, and shaken at $150 \mathrm{rpm}$. The flocculating activity was examined using kaolin clay to check the optimal $\mathrm{pH}$ required for bioflocculant production as indicated above [37].

\subsubsection{Effect of Inoculum Size}

The influence of inoculum volume on bioflocculant production by B. salmalaya strain 139SI was examined because different inoculum sizes exert certain effects on the flocculation activity and cell mass growth. The inoculum sizes used were $0.1 \%, 0.5 \%, 1 \%, 2 \%, 5 \%$, and $10 \%$ [37].

\subsubsection{Effect of Temperature and Shaking Speed}

The B. salmalaya strain 139SI was inoculated into seed media and incubated at $37^{\circ} \mathrm{C}$ on a shaker at $150 \mathrm{rpm}$ for $24 \mathrm{~h}$. From fresh culture of $2 \% v / v$, was inoculated into several sets of $200 \mathrm{~mL}$ bottles containing $50 \mathrm{~mL}$ of production medium, then incubated at different cultivation temperatures were investigated, i.e., $25,30,35,40$ and $45^{\circ} \mathrm{C}$ on shaking $150 \mathrm{rpm}$ for $144 \mathrm{~h}$. Also, the shaking speeds were investigated for different speeds such as 100,120, 140, 160,180, 200 and $220 \mathrm{rpm}$, respectively. The cell free supernatant was obtained by centrifuge at $4000 \mathrm{rpm}$ for $30 \mathrm{~min}$ to separate the cells. Then the flocculating activity was checked.

\subsubsection{Effect of Carbon and Nitrogen Sources}

Bioflocculant production by microorganisms is significantly influenced by carbon and nitrogen sources [32]. These parameters were assessed according to Lachhwani [31]. The growth media were prepared in separate flasks. The bacterial strain was inoculated into the prepared medium. The media were supplemented with $10 \mathrm{~g} / \mathrm{L}$ each of various carbon sources, incubated at $35.5^{\circ} \mathrm{C}$, and shaken at $150 \mathrm{rpm}$ for 7 days. To determine the influence of nitrogen on bioflocculant production, $1.5 \mathrm{~g} / \mathrm{L}$ each of various nitrogen sources was integrated into the fermentation medium in separate containers, and the flocculation activity was calculated according to Lachhwani using Equation (1) [31]. 


\subsection{Bioflocculant Production by B. salmalaya Strain 139SI-7}

Seed culture was prepared by inoculating $5 \%(v / v)$ of bacterial suspension in $50 \mathrm{~mL}$ of enriched medium, followed by overnight incubation at $35.5^{\circ} \mathrm{C}$ and $160 \mathrm{rpm}$. For the optical density (OD600) test, sterile saline water was used to dilute the fermented broth to $0.1 \%$ [57]. In $500 \mathrm{~mL}$ of production medium, the optimized bacterial suspension was inoculated, incubated at $35.5^{\circ} \mathrm{C}$, and shaken at $160 \mathrm{rpm}$ for 7 days. A $10 \mathrm{~mL}$ aliquot of the sample was collected periodically at timed intervals of $24 \mathrm{~h}$, and $5 \mathrm{~mL}$ of the fermented broth was centrifuged. The obtained supernatant was used for the determination of bioflocculant activity following the methods of Kurane and Nohata [56]. The rate of bacterial growth was monitored via bacterial count using the standard plate method and $\mathrm{OD}_{600}$. The $\mathrm{pH}$ and flocculating activity were also determined during the study.

\subsection{Extraction and Purification of Bioflocculants}

At the end of the fermentation period, the culture was subjected to centrifugation for $15 \mathrm{~min}$ at $3500 \mathrm{rpm}$ to separate pelleted bacterial cells. The extracted supernatant was mixed with one volume $(v / v)$ of sterile distilled water, followed by centrifugation for $15 \mathrm{~min}$ at $3500 \mathrm{rpm}$ to remove insoluble materials. Furthermore, the supernatant was mixed with two volumes of cold ethanol (1:2). The sample was thoroughly mixed with a stirrer and allowed to stand at $4{ }^{\circ} \mathrm{C}$ for $12 \mathrm{~h}$. Subsequently, the precipitate was extracted. The obtained crude polymer was dissolved in sterile distilled water. The solution sample was then mixed with chloroform and n-butyl-alcohol in proportion $(5: 2, v / v)$ with stirring and allowed to stand at room temperature overnight. The upper surface portion was separated and subjected to centrifugation at $3500 \mathrm{rpm}$ for $15 \mathrm{~min}$ to obtain a pure bioflocculant [3]. The purified supernatant was concentrated at $40{ }^{\circ} \mathrm{C}$. To recover the precipitate, two volumes of ethanol were added. Finally, the precipitate was vacuumed, dried, dissolved in deionized water to obtain a pure bioflocculant (2.75 g/L) [38], and coded as bioflocculant QZ-7.

\subsection{Characterization of the Bioflocculant QZ-7}

\subsubsection{Chemical Analysis}

Total carbohydrate concentration of the bioflocculant QZ-7 was assayed by the phenol-sulfuric acid method according to Chaplin and Kennedy [45], in which glucose solution was used to determine the standard curve. For uronic acid, the carbazole assay is the method used for detecting and quantifying free and polymeric uronic acids according to Chaplin and Kennedy [45]. The protein concentration was assayed using the Folin-Lowry method, in which bovine serum albumin served as a standard solution [31].

\subsection{2. $\mathrm{pH}$ Stability of Pure Bioflocculant QZ-7}

The bioflocculant QZ-7 $2 \mathrm{mg} / \mathrm{mL}$ was dissolved in $10 \mathrm{~mL}$ of deionized water to reach an initial flocculation activity above $85 \%$. It was then separated into seven samples. The samples were adjusted to $\mathrm{pH} 4,5,6,7,8,9$, and 10 with $1 \mathrm{~N} \mathrm{HCl}$ or $1 \mathrm{~N} \mathrm{NaOH}$. The samples were kept standing at $4{ }^{\circ} \mathrm{C}$ for 1 day [58]. Then, $4 \mathrm{~g} / \mathrm{L}$ kaolin suspension was prepared and adjusted to $\mathrm{pH} 7 \pm 0.2$ the mixed solution was stirred $2 \mathrm{~min}$ at $220 \mathrm{rpm}$, then another round agitated for $10 \mathrm{~min}$ at $100 \mathrm{rpm}$ and kept standing for $5 \mathrm{~min}$. Flocculation activity was determined at room temperature.

\subsubsection{Thermo-Stability of Pure Bioflocculant QZ-7}

Purified bioflocculant QZ-7 $2 \mathrm{mg} / \mathrm{mL}$ was dissolved in $10 \mathrm{~mL}$ of distilled water to determine the optimum flocculation activity and then divided into five groups with $\mathrm{pH} 3,5,7,9$, and 11 . The samples of each $\mathrm{pH}$ value were tested at $20^{\circ} \mathrm{C}, 30^{\circ} \mathrm{C}, 40^{\circ} \mathrm{C}, 50{ }^{\circ} \mathrm{C}, 60^{\circ} \mathrm{C}, 80^{\circ} \mathrm{C}$, and $100{ }^{\circ} \mathrm{C}$ for $60 \mathrm{~min}$ in a water bath [58]. The kaolin suspension $(4 \mathrm{~g} / \mathrm{L})$ was adjusted to $\mathrm{pH} 7 \pm 02$, stirred for $2 \mathrm{~min}$ at $220 \mathrm{rpm}$, 
and agitated again at $100 \mathrm{rpm}$ for $10 \mathrm{~min}$, and allowed to stand for $5 \mathrm{~min}$. The flocculation activity was determined at room temperature.

\subsubsection{Fourier-Transform Infrared Spectroscopy (FTIR)}

The purified bioflocculant was further subjected to FTIR. The purified bioflocculant QZ-7 was blended with potassium bromide and compressed into a disc to obtain translucent pellets for FTIR analysis. The background reference compound used was the pelleted form of potassium bromide. Infrared absorption spectra were recorded with a Spectrum 400 instrument (PerkinElmer, Waltham Massachusetts (MA), USA). The spectral resolution and wave number accuracy were $400-4000 \mathrm{~cm}^{-1}$ under ambient conditions [59].

\subsubsection{Determination of Molecular Weight of Purified Bioflocculant}

The molecular weight of QZ-7 was determined using a TSK G4000 PWXL column operated at $40{ }^{\circ} \mathrm{C}$ via high-performance gel permeation chromatography (HPGPC) coupled to a refractive index (RI) detector (Shimadzu). The column was calibrated using dextran standards. The mobile phase was deionized-distilled (DDI) water at a flow rate of $0.6 \mathrm{~mL} / \mathrm{min}$. Before injection, the sample was filtered through a $0.45 \mu \mathrm{m}$ filter $[55,60]$. The following regression equation was obtained:

$$
\log (\text { mass })=\mathrm{K}_{1} \mathrm{~T}+\mathrm{K}_{2}
$$

where mass $(\mathrm{Da})$ and $\mathrm{T}(\mathrm{min})$ are the molecular mass and retention time of the samples, respectively, and $\mathrm{K}_{1}$ and $\mathrm{K}_{2}$ are constants.

\subsubsection{Scanning Electron Microscopy (SEM) Remarks}

The SEM remarks were examined. The purified bioflocculant QZ-7 powder was spread and fixed on the iron stub. The fixed sample was scanned using SEM (HITACHI- SU8220, Tokyo, Japan).

\subsection{Removal of COD from Wastewater with Bioflocculant QZ-7}

Approximately $0.3 \mathrm{~g}$ of the prepared bioflocculant QZ-7 was added to $100 \mathrm{~mL}$ of filtered wastewater. The physio-chemical characteristics of the raw wastewater were; $4018 \mathrm{mg} / \mathrm{L} \mathrm{BOD,}$ $15,268 \mathrm{mg} / \mathrm{L}$ COD, 17,832 mg/L TDS, and $500 \mathrm{NTU}$ color. The system was agitated with a magnetic stirrer at room temperature for $2 \mathrm{~min}$ at $200 \mathrm{rpm}$ and for $10 \mathrm{~min}$ at $50 \mathrm{rpm}$. The samples were left to stand for $15 \mathrm{~min}$ and clarified through a $0.45 \mu \mathrm{m}$ membrane filter paper. The final COD was determined via the closed reflux colorimetric method [61] The COD removal rate was calculated using the following equation:

$$
\mathrm{R}=\left[\left(\mathrm{COD}_{\mathrm{i}}-\mathrm{COD}_{\mathrm{f}}\right) / \mathrm{COD}_{\mathrm{i}}\right] \times 100
$$

where $\mathrm{R}$ is the removal rate in $\%, \mathrm{COD}_{\mathrm{i}}$ is the $\mathrm{COD}$ concentration of the wastewater before treatment, and $\mathrm{COD}_{\mathrm{f}}$ is the $\mathrm{COD}$ concentration of the wastewater after treatment.

\subsection{Removal of BOD from Wastewater with B. salmalaya Strain 139SI-7}

The removal of BOD from wastewater with B. salmalaya strain 139SI was carried out using two diluted samples. The initial dissolved oxygen $\left(\mathrm{DO}_{\mathrm{i}}\right)$ of the first sample was measured using a $\mathrm{DO}$ meter. The other sample was inoculated with $10 \%$ of the bacterial suspension and incubated in a BOD incubator for 5 days. The final dissolved oxygen $\left(\mathrm{DO}_{\mathrm{f}}\right)$ was measured after 5 days. The BOD was calculated using Equation (4) [61] and the BOD removal percentage was calculated using the following equation:

$$
\mathrm{BOD}(\mathrm{mg} / \mathrm{L})=\mathrm{DO}_{\mathrm{i}}-\mathrm{DO}_{\mathrm{f}}
$$


Author Contributions: Z.M.A.T., conceptualization, methodology, formal analysis and writing. S.I., supervision, funding acquisition, writing-review \& editing. A.D., ting-review \& editing. M.U., writing-review \& editing.

Funding: This study was supported by the University of Malaya, UMRG Programme under Grant No. RP023A-14 AFR.

Conflicts of Interest: The authors declare no conflict of interest.

\section{References}

1. Zhang, C.L.; Cui, Y.N.; Wang, Y. Bioflocculant produced from bacteria for decolorization, Cr removal and swine wastewater application. Sustain. Environ. Res. 2012, 22, 129-134.

2. Zhang, Z.Q.; Lin, B.; Xia, S.Q.; Wang, X.J.; Yang, A.M. Production and application of a novel bioflocculant by multiple-microorganism consortia using brewery wastewater as carbon source. J. Environ. Sci. 2007, 19, 667-673. [CrossRef]

3. Gao, J.; Bao, H.Y.; Xin, M.X.; Liu, Y.X.; Li, Q.; Zhang, Y.F. Characterization of a bioflocculant from a newly isolated Vagococcus sp. W31. J. Zhejiang Univ. Sci. B 2006, 7, 186-192. [CrossRef] [PubMed]

4. Czemierska, M.; Szczes, A.; Hołysz, L.; Wiater, A.; Wilkołazka, A.J. Characterization of exopolymer R-202 isolated from Rhodococcus rhodochrous and its flocculating properties. Eur. Polym. J. 2017, 88, 21-33. [CrossRef]

5. Prasad, K.; Ramanathan, A.; Paul, J.; Subramanian, V.; Prasad, R. Biosorption of arsenite $\left(\mathrm{As}^{+3}\right)$ and arsenate $\left(\mathrm{As}^{+5}\right)$ from aqueous solution by Arthrobacter sp. biomass. Environ. Technol. 2013, 34, 2701-2708. [CrossRef] [PubMed]

6. Zhang, J.; Ding, T.; Zhang, Z.; Xu, L.; Zhang, C. Enhanced adsorption of trivalent arsenic from water by functionalized diatom silica shells. PLoS ONE 2015, 10, e0123395. [CrossRef] [PubMed]

7. Salehizadeh, H.; Shojaosadati, S.A. Extracellular biopolymeric flocculants: Recent trends and biotechnological importance. Biotechnol. Adv. 2001, 19, 371-385. [CrossRef]

8. Zhong, C.; Cao, G.; Rong, K.; Xia, Z.; Peng, T.; Chen, H.; Zhao, J. Characterization of a microbial polysaccharide-based bioflocculant and its anti-inflammatory and pro-coagulant activity. Colloids Surf. B Biointerfaces 2018, 161, 636-644. [CrossRef] [PubMed]

9. Salehizadeh, H.; Shojaosadati, S.A. Removal of metal ions from aqueous solution by polysaccharide produced from Bacillus firmus. Water Res. 2003, 37, 4231-4235. [CrossRef]

10. Salehizadeh, H.; Yan, N. Recent advances in extracellular biopolymer flocculants. Biotechnol. Adv. 2014, 32, 1506-1522. [CrossRef] [PubMed]

11. Campbell, A. The potential role of aluminium in Alzheimer's disease. Nephrol. Dial. Transplant. 2002, 17, 17-20. [CrossRef] [PubMed]

12. Deng, S.; Yu, G.; Ting, Y.P. Production of a bioflocculant by Aspergillus parasiticus and its application in dye removal. Colloids Surf. B Biointerfaces 2005, 44, 179-186. [CrossRef] [PubMed]

13. Takagi, H.; Kadowake, K. Purification and chemical properties of a flocculant produced paecilomyces. Agric. Biol. Chem. 1985, 49, 3159-3164. [CrossRef]

14. Shih, L.; Van, Y.T.; Yeh, L.C.; Lin, H.G.; Chang, Y.N. Production of a biopolymer flocculant from Bacillus licheniformis and its flocculation properties. Bioresour. Technol. 2001, 78, 267-272. [CrossRef]

15. Takeda, M.; Kurane, R.; Kozumi, J.; Nakamura, I. Bioflocculant produced by Rhodococcus erythroplis. Agric. Biol. Chem. 1992, 55, 2663-2664.

16. Takeda, M.; Kurane, R. Localization of a biopolymer produced by Rhodococcus erythropolis grown on n-Pentadecane. Agric. Biol. Chem. 1991, 55, 2665-2666. [CrossRef]

17. Yokoi, H.; Arima, T.; Hayashi, S.; Takasaki, Y. Flocculation properties of poly ( $\gamma$-glutamic acid) produced by Bacillus subtilis. J. Ferment. Bioeng. 1996, 82, 84-87. [CrossRef]

18. Toeda, K.; Kuranem, R. Microbial flocculant from Alkaligenes cupidus KT201. Agric. Biol. Chem. 1991, 55, 2793-2799.

19. Wang, Z.; Wang, K.; Xie, Y. Bioflocculant producing microorganism. Chin. Sci. Abstr. Ser. B 1995, 3, 14.

20. Lee, S.H.; Lee, S.O.; Jang, K.L.; Lee, T.H. Microbial flocculant from Arcuadendron sp. Ts-49. Biotechnol. Lett. 1995, 17, 95-100. [CrossRef]

21. Yaeger, R.G. Protozoa: Structure, Classification, Growth, and Development. In Medical Microbiology, 4th ed.; Baron, S., Ed.; University of Texas Medical Branch: Galveston, TX, USA, 1996. 
22. Bunk, B.; Biedendieck, R.; Jahn, D.; Vary, P.S. Bacillus Megaterium and other Bacilli: Industrial Applications. Encycl. Ind. Biotechnol. 2010. [CrossRef]

23. Perez-Garcia, A.; Romero, D.; de Vicente, A. Plant protection and growth stimulation by microorganisms: Biotechnological applications of Bacilli in agriculture. Curr. Opin. Biotechnol. 2011, 22, 187-193. [CrossRef] [PubMed]

24. Priest, F.G.; Goodfellow, M.; Shute, L.A.; Berkeley, R.C.W. Bacillus amyloliquefaciens sp. nov. norn. rev. Int. J. Syst. Bacteriol. 1987, 37, 69-71. [CrossRef]

25. He, J.; Zou, J.; Shao, Z.; Zhang, J. Characteristics and flocculating mechanism of a novel bioflocculant HBF-3 produced by deep-sea bacterium mutant Halomona sp. V3a. World J. Microbiol. Biotechnol. 2010, 26, 1135-1141. [CrossRef]

26. Zhao, G.; Ma, F.; Wei, L.; Chua, H. Using rice straw fermentation liquor to produce bioflocculants during an anaerobic dry fermentation process. Bioresour. Technol. 2012, 113, 83-88. [CrossRef] [PubMed]

27. Yang, H.; Xiao, J.; Wang, F.; Zhang, L. Adsorption-flocculation of Rhodococcus erythropolis on micro- fine hemalitic. J. Cent. South Univ. 2013, 44, 874-879.

28. Okaiyeto, K.; Nwodo, U.V.; Mabinya, L.V.; Okoh, A.I. Evaluation of the flocculation potential and characterization of bioflocculant produced by Micrococcus sp. Leo. Appl. Biochem. Microbial. 2014, 50, 601-608. [CrossRef]

29. Tang, J.; Qi, S.; Li, Z.; An, Q.; Xie, M.; Yang, B.; Wang, Y. Production, purification and application of polysaccharide-based bioflocculant by Paenibacillus mucilaginosus. Carbohydr. Polym. 2014, 113, 463-470. [CrossRef] [PubMed]

30. Fujita, M.; Ike, M.; Tachibana, S.; Kitada, G.; Kim, S.M.; Inoue, Z. Charactrisation of bioflocculant produced by Citrobactor sp. TKF04 from acetic and propionic acids. J. Biosci. Bioeng. 2000, 89, 40-46. [CrossRef]

31. Lachhwani, P. Studies on Polymeric Bioflocculant Producing Microorganisms. Master's Thesis, Thapar Institute of Engineering and Technology, Patiala, India, 2005.

32. Xia, S.; Zhang, Z.; Wang, X.; Yang, A.; Chen, L.; Zhao, J.; Leonard, D.; Renault, N.J. Production and characterization of a bioflocculant by Proteus mirabilis Tj-1. Bioresour. Technol. 2008, 99, 6520-6527. [CrossRef] [PubMed]

33. Nakata, K.; Kurane, R. Production of an extracellular polysaccharides on bioflocculant producing by Klebsiella pneumoniae. Biosci. Biotechnol. Biochem. 1999, 63, 2064-2068. [CrossRef] [PubMed]

34. Wang, S.-G.; Gong, W.-X.; Liu, X.-W.; Tian, L.; Yue, Q.-Y.; Gao, B.-Y. Production of a novel bioflocculant by culture of klebsiella mobilis using dairy wastewater. Biochem. Eng. J. 2007, 36, 81-86. [CrossRef]

35. Zhang, Z.; Wu, C.; Wu, Y.; Hu, C. Comparison of coagulation performance and floc properties of a novel zirconium-glycine complex coagulant with traditional coagulants. Environ. Sci. Pollut. Res. 2014, 21, 6632-6639. [CrossRef] [PubMed]

36. Li, L.; Ma, F.; Zuo, H. Production of a novel bioflocculant and its flocculation performance in aluminum removal. Bioengineered 2016, 7, 98-105. [CrossRef] [PubMed]

37. Aljuboori, A.H.R.; Idris, A.; Abdullah, N.; Mohamad, R. Production and characterization of a bioflocculant produced by Aspergillus flavus. Bioresour. Technol. 2013, 127, 489-493. [CrossRef] [PubMed]

38. Rasulov, B.; Li, L.; Liu, Y.; Mohammed, O.; Xiao, M.; Ma, J. Production, characterization and structural modification of exopolysaccharide-based bioflocculant by Rhizobium radiobacter SZ4S7S14 and media optimization. Biotechnology 2017, 179. [CrossRef] [PubMed]

39. Zheng, Y.; Ye, Z.-L.; Fang, X.-L.; Li, Y.-H.; Cai, W.-M. Production and characteristics of a bioflocculant produced by Bacillus sp. F19. Bioresour. Technol. 2008, 99, 7686-7691. [CrossRef] [PubMed]

40. Ugbenyen, A.M.; Cosa, S.; Mabinya, L.V.; Okoh, A.I. Bioflocculant production by Bacillus sp. Gilbert isolated from a marine environment in South Africa. Appl. Biochem. Microbiol. 2014, 50, 49-54. [CrossRef]

41. Ismail, B.; Nampoothiri, K.M. Production, purification and structural characterization of an exopolysaccharide produced by a probiotic Lactobacillus plantarum MTCC 9510. Arch. Microbiol. 2010, 192, 1049-1057. [CrossRef] [PubMed]

42. Li, Z.; Zhong, S.; Lei, H.; Chen, R.; Yu, Q.; Li, H. Production of a novel bioflocculant by Bacillus licheniformis X14 and its application to low temperature drinking water treatment. Bioresour. Technol. 2009, 100, 3650-3656. [CrossRef] [PubMed]

43. Lu, W.Y.; Zhang, T.; Zhang, D.Y.; Li, C.H.; Wen, J.P.; Du, L.X. A novel bioflocculant produced by Enterobacter aerogenes and its use in defecating the trona suspension. Biochem. Eng. J. 2005, 27, 1-7. [CrossRef] 
44. Wu, J.Y.; Ye, H.F. Characteristic and flocculating properties of an extracellular biopolymers from Bacillus subtilis D4U, isolate. Process. Biochem. 2007, 42, 1114-1123. [CrossRef]

45. Chaplin, M.F.; Kennedy, J.F. Carbohydrate Analysis, 2nd ed.; Oxford University Press: New York, NY, USA, 1994.

46. Aguilera, M.; Quesada, M.T.; Aguila, V.G.; Morillo, J.A.; Rivadeneyra, M.A.; Cormenzana, A.R.; Sanchez, M.M. Charaterization of paenibacillus jamilae stains that produce exopolysaccharides during growth on and detoxification of olive mill wastewater. Bioresour. Technol. 2008, 99, 5640-5644. [CrossRef] [PubMed]

47. Sun, P.; Hui, C.; Bai, N.; Yang, S.; Wan, L.; Zhang, Q.; Zhao, Y. Revealing the characteristics of a novel bioflocculant and its flocculation performance in Microcystis aeruginosa removal. Sci. Rep. 2015. [CrossRef] [PubMed]

48. Suh, H.H.; Kwon, G.S.; Lee, C.H.; Kim, H.S.; Oh, H.M.; Yoon, B.D. Characterisation of bioflocculant produced by Bacillus sp. DP-152. Ferment. Bioeng. 1997, 84, 108-112. [CrossRef]

49. Gupta, S.; Madan, R.N.; Bansal, M.C. Chemical composition of pinus carbaea hemicellulose. Tappi J. 1987, 70, 113-114.

50. Yang, Q.; Ming, H.; Zhao, X.; Zhang, J.; Zou, W.; Zhao, C.; Guan, X. Screening of bioflocculant and preliminary application to treatment of tannery wastewater. J. Resid. Sci. Technol. 2015, 12, 177-181. [CrossRef]

51. Lian, B.; Chen, Y.; Zhao, J.; Teng, H.H.; Zhu, L.J.; Yuan, S. Microbial flocculation by Bacillus mucilaginosus; application and mechanism. Bioresour. Technol. 2008, 99, 4825-4831. [CrossRef] [PubMed]

52. Yong, P.; Bo, S.; Yu, Z. Research on flocculation property of bioflocculant. PG. a21 ca. Mod. Appl. Sci. 2009, 3, 106-112.

53. Alehizadeh, H.; Yan, N.; Farnood, R. Recent advances in polysaccharide bio-based flocculants. Biotechnol. Adv. 2018, 36, 92-119. [CrossRef] [PubMed]

54. Ismail, S.; Dadrasnia, A. Biotechnological potential of Bacillus salmalaya 139SI: A novel strain for remediating water polluted with Crude Oil Waste. PLoS ONE 2015, e0120931. [CrossRef] [PubMed]

55. Xiong, Y.; Wang, Y.; Yu, Y.; Li, Q.; Wang, H.; Chen, R.; He, N. Production and characterisation of a novel bioflocculant from Bacillus Licheniformis. Appl. Environ. Microbial. 2010, 76, 2778-2782. [CrossRef] [PubMed]

56. Kurane, R.; Nohata, Y. A new water-absorbing polysaccharide from Alcaligenes latus. Biosci. Biotechnol. Biochem. 1994, 58, 235-238. [CrossRef]

57. Cosa, S.; Mabinya, L.V.; Olaniran, A.O.; Okoh, A.I. Production and characterization of bioflocculant produced by Halobacillus sp. Mvuyo isolated from bottem sediment of Algoa Bay. Environ. Technol. 2012, 33, 967-973. [CrossRef] [PubMed]

58. He, N.; Li, Y.; Chen, J. Production of a novel polygalacturoic acid bioflocculant REA-11 by Corynebacterium glutamicum. Bioresour. Technol. 2004, 94, 99-105. [CrossRef] [PubMed]

59. Gomaa, E.Z. Production and characteristics of a heavy metals removing bioflocculant produced by Pseudomonas aeruginosa. Pol. J. Microbiol. 2012, 61, 281-289.

60. Chen, Z.; Li, Z.; Liu, P.; Wang, Y.; Li, Q.; He, N. Characterization of a novel bioflocculant from a marine bacterium and its application in dye wastewater treatment. BMC Biotechnol. 2017, 17, 84. [CrossRef] [PubMed]

61. Rice, W.; Baird, R.B.; Eaton, A.D.; Clesceri, L.S. Standard Methods for the Examination of Water and Wastewater, 21st ed.; American Public Health Association (APHA), American Water Works Association (AWWA) and Water Environment Federation (WEF): Washington, DC, USA, 2005.

Sample Availability: Samples of the compounds are available from the authors. 